VOLUME 17 | ISSUE 1

March 2012

ISSN: 1092-8529
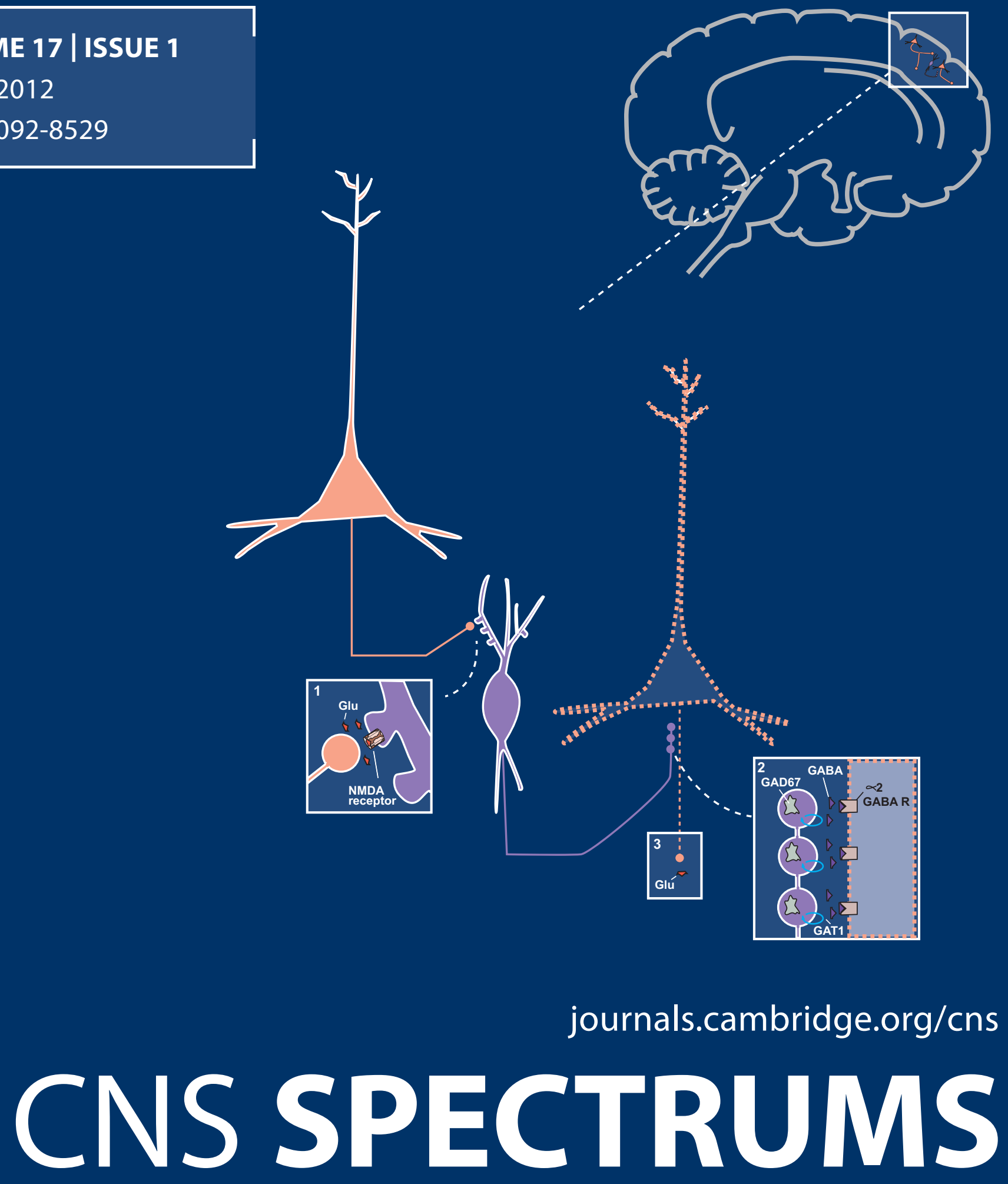

EDITOR-IN-CHIEF: STEPHEN M. STAHL 


\section{NEI MEMBERSHIP}

Join NEI today and strengthen your clinical practice.

Become the "go-to" clinician in your specialty using NEI Member benefits.

Stay current reading CNS Spectrums Journal online.

Obtain CME credits at no additional cost.

Become an NEI Master Psychopharmacologist.

Access online learning and practice resources.

Enjoy discounts on the NEI Congress and other events.

And much more!

Use promotion code SPECTRUMS1 to join NEI at $\mathbf{\$ 5 0}$ off the regular New Member rate. *

* Cannot be used in combination with other sales or promotions.

Call us at 1-888-535-5600 or visit www.neiglobal.com today! 


\section{CAMBRIDGE}

\section{Medicine}
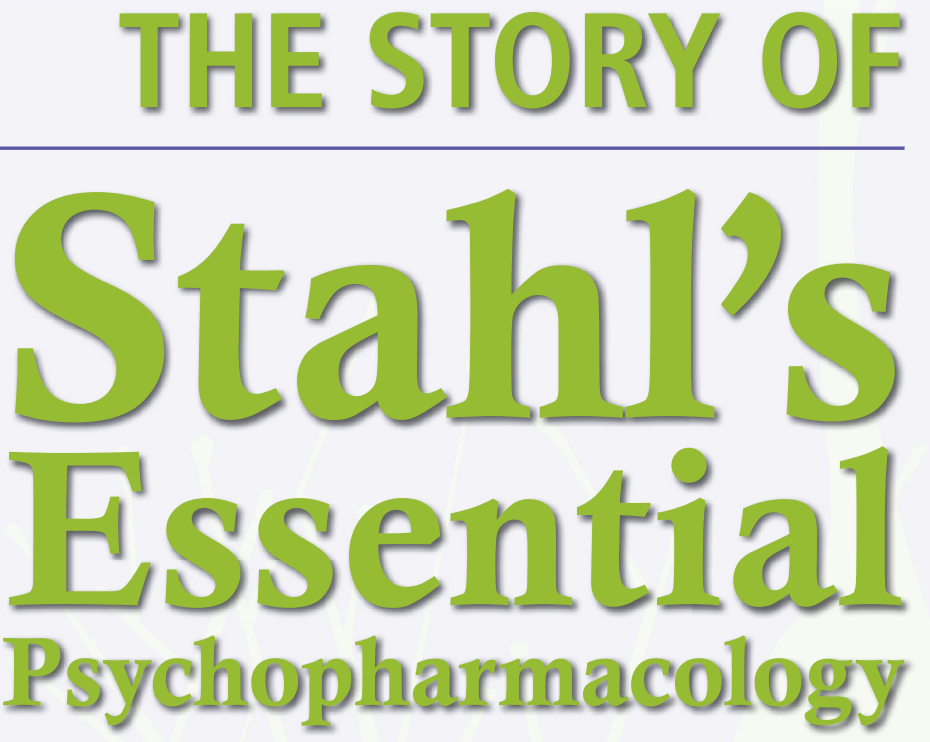

The Essential Psychopharmacology franchise began 17 years ago as a published offshoot of my lectures for mental health professionals.

I have always had to 'see' something before I could understand it, especially disease mechanisms and drug actions, and thus developed a compendium of figures and diagrams for my lectures. With my long term illustrator Nancy Muntner, we gradually developed a 'visual language' for psychopharmacology with icons and figures that have become the signature feature of Stahl's Essential Psychopharmacology.

The original textbook - Stahl's Essential Psychopharmacology - explained how drugs work but not how to use them, so the Prescriber's Guide was created as a companion to the textbook. For this, in addition to our characteristic use of unique icons, we also included standard evidence based drug information. I also added 'tips and pearls' based on the art of psychopharmacology and derived as much from my experience in clinical practice as from the evidence.

More recently, we added the third leg of the stool. The Case Studies book is about living through the treatments that work, the treatments that fail, and the mistakes made along the journey. This is psychiatry in real life, these are the patients from your waiting room. The intention of the book is that it will reassure, inform, and guide better clinical decision making.

And now, in early 2012, I am pleased to announce the publication of a brand new book of self-assessment questions in psychiatry.

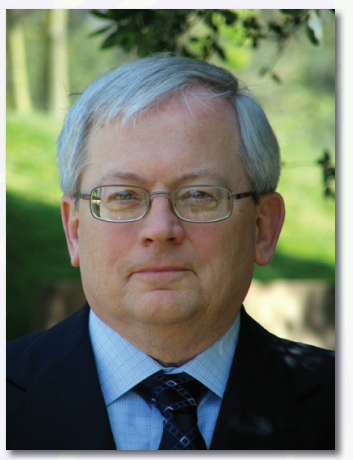

\section{Stahl's Essential Psychopharmacology - four 'must-haves'}

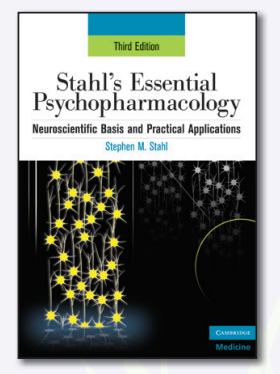

Stahl's Essential Psychopharmacology:

Neuroscientific Basis and Practical Applications Third Edition

- Long established as the preeminent source of education and information in its field

- Features the author's highly-praised writing style and clear, easy-to-follow illustrations

- Thoroughly updated and much-expanded for the third edition, taking account of advances in neurobiology and recent clinical developments to explain the concepts underlying the drug treatment of psychiatric disorders

978-0-521-67376-1 • Pbk • $1132 \mathrm{pp} \bullet 2008 \bullet \$ 99.99$

\section{new edition}

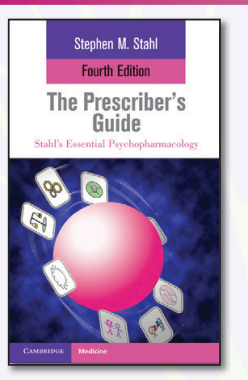

The Prescriber's Guide

Fourth edition

- Completely revised and updated edition of the most widelyused prescribing guide specifically for psychopharmacology

- With new drug additions, and every drug entry revised and updated to take into account new regulations and uses

- Full color throughout, with information distilled into pragmatic formulary that gives all information that prescribers need to treat patients effectively

978-0-521-17364-3 • Pbk • $712 \mathrm{pp} \bullet 2011 \bullet \$ 75$

\section{new}

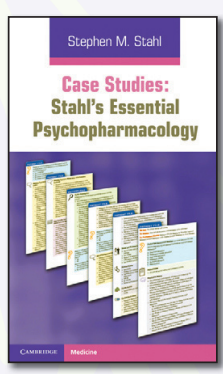

\section{Case Studies}

Designed with the distinctive, user-friendly presentation that has been so popular in Stahl's Essential Psychopharmacology and The Prescriber's Guide

- Describes a wide-ranging and representative selection of clinical scenarios, making use of icons, questions/answers and tips

- Cases are followed through the complete clinical encounter, from start to resolution, acknowledging all the complications, issues, decisions, twists and turns along the way

- Psychiatry in real life!

978-0-521-18208-9 • Pbk • $408 \mathrm{pp} \bullet 2011 \bullet \$ 65$

\section{coming soon}

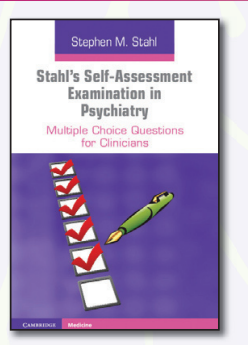

Stahl's Self-Assessment Examination in Psychiatry Multiple Choice Questions for Clinicians

- 150 self-assessment questions that will help the reader to identify areas of competence or the need for further study

- Ideal for exam preparation and also as training tools for those working in related clinical fields and in industry

978-1-107-68159-0 • Pbk • 344 pp • May 2012 •\$49.99

www.cambridge.org/us/stah 


\section{CAMBRIDGE}

\section{JDURNALS}

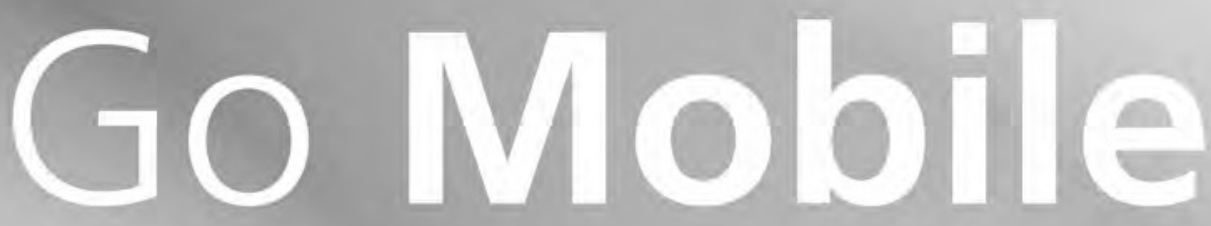

CJO Mobile (CJOm) is a streamlined

Cambridge Journals Online (CJO)

for smartphones and other small mobile devices

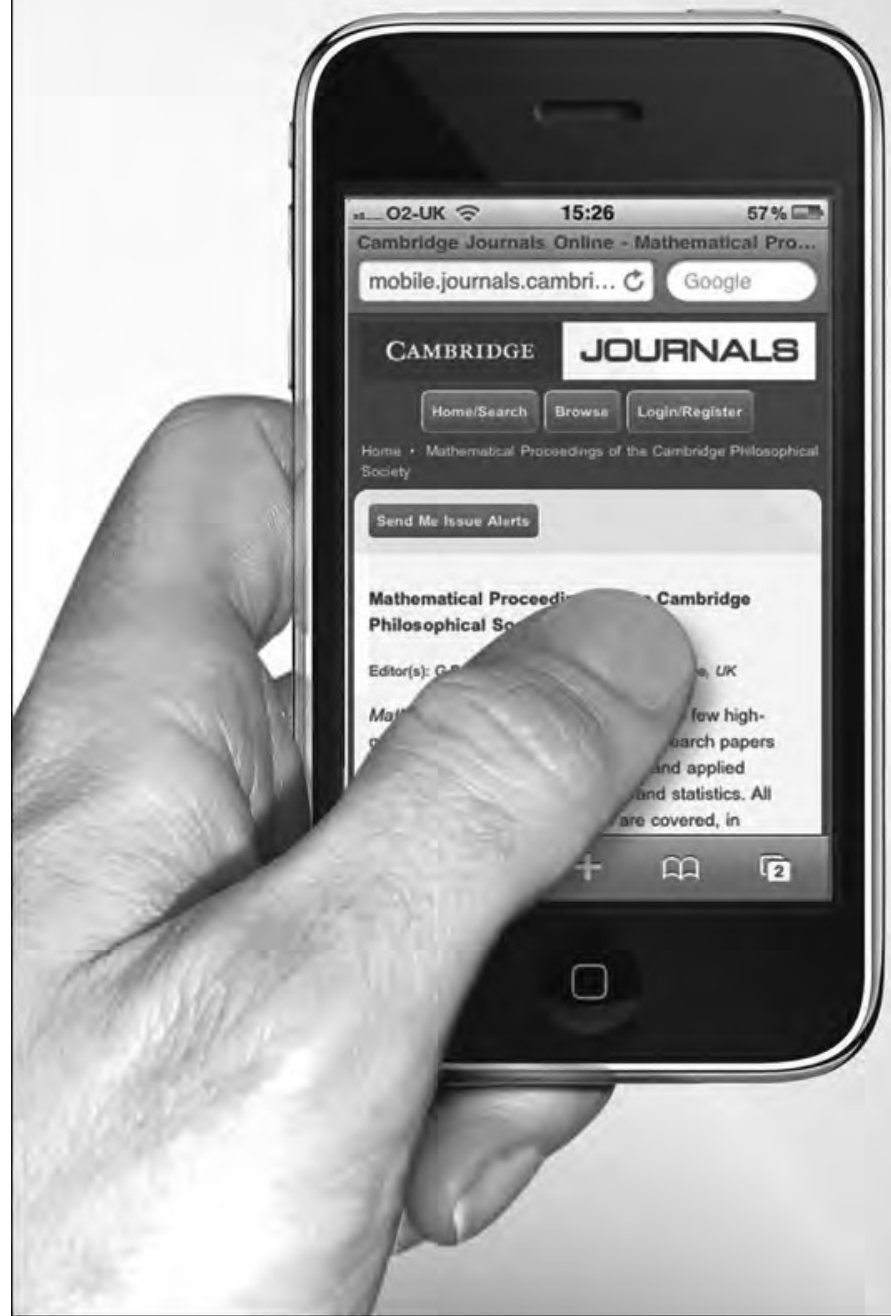

- Use CJOm to access all journal content including FirstView articles which are published online ahead of print

- Access quickly and easily thanks to simplified design and low resolution images

- Register for content alerts or save searches and articles they will be available on both CJO and CJOm

- Your device will be detected and automatically directed to CJOm via: journals.cambridge.org 


\section{CNS SPECTRUMS}

\section{CONTENTS}

EDITORIAL

From the Editor

Stephen M. Stahl

REVIEW ARTICLE

Practical Guide for Prescribing MAOls: Debunking Myths and Removing Barriers

Meghan M. Grady and Stephen M. Stahl

ORIGINAL RESEARCH ARTICLES

Post-traumatic Stress Disorder Symptom Severity in Service Members Returning from Iraq and Afghanistan with Different Types of Injuries Robert N. McLay, Jennifer Webb-Murphy,

Paul Hammer, Stacy Volkert and Warren Klam

Trial-based Psychotherapy and the Efficacy of Trial-based Thought Record in Changing Unhelpful Core Beliefs and Reducing Self-criticism

Irismar Reis de Oliveira, Curt Hemmany, Vania B. Powell, Thaís D. Bonfim, Érica P. Duran, Nilma Novais, Michella Velasquez, Elaine Di Sarno, Gledson L. Alves, Joici A. Cesnik and on behalf of the Brazilian TBTR Study Group
rTMS Age-dependent Response in Treatmentresistant Depressed Subjects: A Mini-review

1 Stefano Pallanti, Andrea Cantisani, Giacomo Grassi, Sarah Antonini, Chiara Cecchelli, Jiulia Burian, Gilla Cauli and Leonardo Quercioli

Strategies for Optimizing Medication Adherence in Schizophrenia (CME article)

Debbi A. Morrissette and Andrew J. Cutler ABSTRACTS

2011 NEI Global Psychopharmacology Congress 


\section{Editorial Staff}

Editor-in Chief

Stephen M. Stahl, MD, PhD, Adjunct Professor of Psychiatry at the University of California San Diego, Honorary Visiting Senior Fellow at the University of Cambridge, UK.

Content Editor

Lisa Arrington, Cambridge University Press (larrington@cambridge.org)

(c) Cambridge University Press 2012. All rights reserved.

No part of this publication may be reproduced, in any form or by any means, electronic, photocopying, or otherwise, without permission in writing from Cambridge University Press. Policies, request forms, and contacts are available at: http://www. cambridge.org/rights/permissions/permission.htm. Permission to copy (for users in the U.S.A.) is available from Copyright Clearance Center http://www.copyright.com, email:info@copyright.com.

Rights \& permissions requests can be applied for online within each article by clicking "Request Permissions" within the table of contents or in the fulltext version of a specific article. Requests will be processed via the CCC Rightslink system and processed immediately.

CNS Spectrums (ISSN: Print 1092-8529; elSSN: 2165-6509) is published quarterly by Cambridge University Press.

\section{Aims and Scopes}

CNS Spectrums aims to be the premiere journal covering all aspects of clinical neurosciences, neurotherapeutics and neurospsychopharmacology. From 2012 the journal will primarily focus on the publication of authoritative, cross-disciplinary review and opinion material publishing advances and controversial issues with pertinence to the clinician. In particular we aim to publish reviews and articles in translational neuroscience, biological psychiatry and neuropsychopharmacology that explain clinically relevant neuroscience discoveries in a way that makes these findings accessible and understandable to clinicians and clinical investigators. We will emphasize new therapeutics of all types in clinical neurosciences, mental health, psychiatry, and neurology, especially first in man studies and proof of concept studies. Our focus will be not just drugs, but novel psychotherapies and neurostimulation therapeutics as well. CNS Spectrums will in addition, continue to publish original research and commentaries that focus on emergent areas of research. Subject coverage shall span the full spectrum of neuropsychiatry focusing on translational issues and those crossing traditional boundaries between neurology and psychiatry.

\section{Submitting Manuscripts to CNS Spectrums}

All submissions to CNS Spectrums, should be prepared in accordance with the instructions for authors and in the style of the Journal. Manuscripts should be submitted through the dedicated CNS Spectrums ScholarOne Manuscripts website: http://mc.manuscriptcentral.com/cnsspectr

CNS Spectrums will consider and encourage the following types of articles for publication: Review Article-Comprehensive article summarizing and synthesizing the literature on various topics presented in a scholarly and clinically relevant fashion; Original Research-Reports the results of a clinical study and contains original research; Opinion-Address a current topic of high interest, which has substantial evidence but has not yet been established; Commentary-An article that is written in reaction to previously published articles; usually encouraging a level of debate; the journal will also include Brainstorms and Editorials that shall be commissioned or written by the Editor in Chief.

Instructions for Contributors

The Instructions for Contributors are available on the Cambridge Journals Online web site at: http://journals.cambridge. org/CNSifc

\section{Indexing}

CNS Spectrums is indexed by Index Medicus/ MEDLINE and Web of Science (Thomson Reuters) as well as appearing in the annual Journal Citation Report. Introduced in 1996, the journal was acquired in whole by Cambridge University Press in November of 2011.

\section{Subscriptions}

Institutions print and electronic: $£ 426 / \$ 660$; Institutions electronic only: $£ 355 / \$ 550$; Individuals print plus electronic: $£ 114 / \$ 138$; Individuals electronic only: $£ 95 / \$ 115$.

\section{Postmaster}

Send address changes in the U.S.A., Canada, and Mexico to CNS Spectrums, Cambridge University Press, Journals Dept., 100 Brook Hill Drive, West Nyack, NY 10994-2133, U.S.A. Send address change elsewhere to CNS Spectrums, Cambridge University Press, The Edinburgh Building, Shaftesbury Road, Cambridge CB2 8RU, England.

\section{Online availability}

CNS Spectrums is hosted on the Cambridge Journals Online (CJO) service at http://journals.cambridge.org/cns

Institutional subscribers: Access to full-text articles online is only granted to subscription options offering an online component. Subscriptions must be activated by the purchasing institution using the instructions provided at the time of purchase; see information for subscribers at: http://journals.cambridge.org/

\section{Reprint and Advertising Sales}

Inquiries for bulk reprint sales and placement of advertising should be sent to the Journals Sales Department of Cambridge University Press: USAdSales@cambridge.org

Cover Image: The image on the cover shows a hypothetical model whereby glutamate is released from an intracortical pyramidal neuron and binds to an NMDA receptor on a GABA-ergic interneuron. GABA is then released and binds to receptors on the axon of another glutamate pyramidal neuron. This inhibits the neuron, thus reducing the release of cortical glutamate. The GABA interneuron and its NMDA synapse from the first neuron to the second is the hypothetical site of glutamate dysfunction in schizophrenia.

Stahl's Essential Psychopharmacology, 4th edition, by Stephen M. Stahl

Copyright (C) 2012 Stephen M. Stahl. Reproduced with permission. 